This is an Accepted Manuscript of an article published by Taylor \& Francis Group in Journal of Map \& Geography Libraries, 13:2, 148-174 on 04/08/2017 DOI:

10.1080/15420353.2016.1249446.

To link to this article: http://dx.doi.org/10.1080/15420353.2016.1249446

To cite this article:

Zellmer, Linda R. (2017) Protected Places: A Survey of Laws on Archaeological Site and Cave Location Confidentiality and Their Potential Impact on Library Reference Policies and Services, Journal of Map \& Geography Libraries, 13:2, 148-174. DOI: 10.1080/15420353.2016.1249446. 


\title{
Protected Places: A Survey of Laws on Archaeological Site and Cave Location Confidentiality and their Potential Impact on Library Reference Policies and Services
}

\begin{abstract}
Librarians who work with maps and other forms of spatial information are often asked for information about the location of a place. These questions can range from the location of a village or farm where an ancestor lived to more cryptic questions, such as the location of the Garden of Eden based on its Biblical description. Most librarians will attempt to answer locational questions by directing users to resources such as gazetteers, atlases, maps and plat books. However, the locations of archaeological sites and caves are protected by Federal and state laws. This article provides a summary of Federal and state laws protecting archaeological sites and caves, the reasons for the laws, issues to consider when asked for locations of archaeological sites and caves, and additionally suggests a policy for dealing with users requesting information about archaeological sites and caves.
\end{abstract}

Keywords: archaeological sites; caves; library reference services; map collections; legal issues; library policies

\section{Introduction}

Picture the following scenarios:

- A library user comes into the map collection on Friday afternoon and declares his plans to go four wheeling over the weekend. He asks for information on the locations of back-country ruins that he can visit.

- A library user comes into the map collection asking for information on the location of caves in the area so that they can go spelunking over the weekend.

- A telephone call comes into the reference desk asking for information on the location of a specific cave (e.g., Truitt Cave).

These are all real questions that have been asked in libraries and map collections. Many new map and geospatial information librarians may not appreciate the wide variety of location information available in their collections and how it can be used, or just as important, misused. To answer these questions, they may direct these users to older gazetteers, county histories, historical maps, field notebooks and other publications without considering the possible ramifications of providing information on the locations of archaeological sites, such as ruins and Indian mounds, and caves. For example, the Arizona volume of The National Gazetteer of the United States of America (United States. Geological Survey 1987) contains the locations of caves as well as some ruins. State, academic and museum libraries and archive collections may have resources, such as historic maps (including historic topographic maps), containing symbols or other notations showing the locations of ruins, Indian mounds and caves. Historic accounts by early explorers or surveyors and county histories may also contain such locations. Field notebooks, which might be included in collections of papers from retired faculty and researchers, could also contain the locations of archaeological sites and caves. Finally, some state geological surveys published volumes on caves in their states (e.g., Caves of Indiana) before the passage of Federal and state cave protection laws. 
Before answering questions on the locations of archaeological sites and caves, librarians need to become aware of the legal protections regarding their locations. Archaeological sites and caves are unique because they are protected by laws that have been passed by Congress and state legislatures, as opposed to other potentially sensitive sites which may be protected by administrative policies or secured after evaluation using criteria such as the guidelines developed by the Federal Geographic Data Committee's Homeland Security Working Group (United States. Federal Geographic Data Committee 2005). Archaeological sites, and the artifacts that may be found at those sites, are protected by several Federal laws as well as laws in all 50 states. Caves are also protected by Federal and some state laws. This article surveys the laws protecting archaeological sites and caves, the reasons the laws were passed, and issues that should be considered when providing information on the location of archaeological sites and caves. It also suggests a policy for librarians to use when responding to such questions.

\section{Archaeological Protection Laws}

In 2009, Federal agents raided eight homes in the Four Corners region of Utah and Colorado, arresting 23 people who were charged with violating provisions of the Archaeological Resources Protection Act and the Native American Graves Protection and Repatriation Act; a total of 32 people were eventually charged (Sharp 2015). They also seized more than 40,000 artifacts from the homes of suspects (ibid.). The artifacts, which are presently in a Salt Lake City, Utah warehouse, will be repatriated to Native American tribes if possible. However, because many of the seized artifacts were not adequately documented with geospatial coordinates, depth at which they were found, and a map or photograph showing their location within a site as well as relationship to other artifacts and remains, their usefulness for archaeological research is limited (ibid.).

Archaeology is "the study of past human behavioural systems within the social, religious, economic, political, biological, geological and geographic contexts" (Ellis 2000, xv). Context refers to the relationship of an artifact to its surroundings, including its depth in an excavation and the associated soil and biological materials, which can be used to date a site. The relationship between an artifact and other nearby objects can be used to determine the function of an area, such as whether it was used as a dwelling, for tool production or, if an object is found with human remains, a grave or burial site (Mignon 1993, 88). Archaeologists combine methods from a wide variety of fields, from history to natural history, to document and analyze the remains of human activity to learn more about past inhabitants' ways of life (Ellis 2000, xv). Archaeologists also preserve a record of the sites that they study by photographing sites and objects that are found during excavation, recording the location of objects within a site, and collecting and preserving biological and cultural materials that are found so that future researchers can examine the artifacts and associated materials that are collected as well as archaeological field notes and photographs made during excavation (Mignon 1993, 156161). Archaeological sites are often the only known remains of past cultures, especially those without written records. Like crime scenes, once archaeological and historic sites are disturbed or destroyed, they cannot be replaced or used to study the past inhabitants and their lives.

Native American and historical artifacts are commercially valuable. According to Dunkel $(1992,13)$ "near pristine Indian jugs and bowls command $\$ 15,000$ or more on the collectibles market." The value of Native American artifacts on the Antiques Roadshow appraisals website range from $\$ 500$ for an Acoma water jar dating from 1900 
to over \$250,000 for a Tlingit oil bowl and ladle (PBS/WGBH Boston). Historically, several Federal laws have been passed dealing with archaeological protection. They include the Antiquities Act of 1906; Historic Sites Act of 1935; National Historic Preservation Act of 1966; Archeological and Historic Preservation Act of 1974 and the Archaeological Resources Protection Act of 1979 (United States. National Park Service 2006).

\section{Antiquities Act of 1906}

The Antiquities Act was passed in response to the demand for Native American artifacts inspired by exhibits at the 1876 Centennial Exposition in Philadelphia and the 1893 Columbian Exposition (World's Fair) in Chicago (Benderson 2015). Lee (2001) describes the plunder of many southwestern archaeological sites that occurred before the law was passed. Walls of cliff dwellings that were occupied from 600 to 1300 ACE, such as those at Mesa Verde National Park and Bandelier National Monument, were destroyed by specimen hunters so that they would have light to excavate within the dwellings. Ceiling support beams from Mesa Verde cliff dwellings, which had survived intact in the dry southwestern climate, were used as firewood (Fewkes 1910, 486-487). One explorer from as far away as Sweden came to the southwestern United States to explore and excavate, taking boxcars of artifacts that he found home to Europe (Lee 2001). Bruce Babbitt identifies three purposes for the Antiquities Act in his introduction to Lee's The Story of the Antiquities Act (ibid). The first is that "archeological, historic, scenic, and scientific sites and structures are most valuable for the archeological, historical, and scientific information they contain, and for their commemorative, scenic, or inspirational associations." The second is that cultural resources, including archaeological and historic sites and historic buildings, have a public value, because they provide evidence of the past and, in the absence of a written record, can be used to reconstruct the history of an area (Lipe 2002). The final reason given by Babbitt was best described by Prudden in 1903:

"to gather or exhume specimens ... without at the same time carefully, systematically, and completely studying the ruins from which they are derived, with full records, measurements, and photographs, is to risk the permanent loss of much valuable data and to sacrifice science for the sake of plunder."

Disturbing the context of archaeological resources destroys the clues that archaeologists use to interpret and reconstruct past inhabitants' way of life and culture (Davis 1972).

Historic Sites Act of 1935

The Historic Sites Act of 1935 was passed to establish a policy of preserving "historic sites, buildings and objects of national significance ... for the inspiration and benefit of the people of the United States" (Historic Sites Act 1935). It was passed after President Franklin D. Roosevelt exercised his power to reorganize the executive branch of the Federal government under the Economy Act of 1933 (Dilsaver 1994). That year, Roosevelt issued two executive orders (6166 and 6228) to transfer responsibility for all national monuments, battlefields, military parks and memorials to the National Park Service (Dilsaver 1994), giving the Park Service responsibility for historic site preservation. In a 1935 Congressional hearing on the bill that became the Historic Sites Act, Interior Secretary Harold Ickes pointed out that the United States was the only Western nation that had not developed a "policy for the preservation of the physical and cultural remains of our history" (United States. Congress. House. Committee on Public Lands 1935). The Act required the Park Service to collect information about historic and archaeological sites, historic buildings, and other objects to protect them for future 
generations. These duties would later be expanded by the National Historic Preservation Act.

\section{National Historic Preservation Act of 1966}

The National Historic Preservation Act of 1966 authorized the Secretary of the Interior to develop and maintain a register of historic districts, sites and structures known as the National Register of Historic Places. The Act also provides funding for matching grants to states and the National Trust for Historic Preservation so that sites can be preserved (Dilsaver 1994). When enacted, urban sprawl and road construction were permanently destroying historic and archaeological sites. Areas being razed were not being assessed for their historic value, and artifacts were not being collected and maintained for future research before construction. To protect historic and archaeological sites from damage, Section 106 of the Act requires that Federal agencies consider the effects of their projects on these sites (National Historic Preservation Act 1966), especially if they receive Federal funding or permits. However, the law also applies to rural areas. Sites on Federal lands that may be damaged by activities such as constructing cell towers, digging for pipelines and oil drilling must also be evaluated before work begins. Researchers working for companies that must comply with Section 106 of the Act rely heavily on map and other archival collections with historic maps and aerial photographs, which they examine during a project's planning stages to determine whether historical and archaeological sites exist before work begins. If evidence of a site is found, a more detailed archaeological excavation will be performed to collect and preserve archaeological, historical, or cultural objects for future research. Alternatively the site plan can be altered to avoid sensitive resources. After an area has been evaluated or excavated, a report is submitted to the state historic preservation office or agency that serves in that role. Texas also requires archaeologists to create short reports without location information, which are sent to state university libraries (Texas Administrative Code 2013); the removal of location information protects sites from looting.

\section{Archeological and Historic Preservation Act of 1974}

The Archeological and Historic Preservation Act of 1974 revised the Reservoir Salvage Act of 1960, an earlier law on archaeological protection that required preservation of historical and archaeological information, relics and specimens that could be lost by building a dam, either through construction or the subsequent inundation of an area by a reservoir (Archeological and Historic Preservation Act 1974). It extended the requirement to preserve archaeological information, relics and specimens to all Federally-funded construction projects that alter the landscape, rather than just dam and reservoir construction (McManamon 2000). It required that either the Secretary of the Interior or the agency funding the project pay for archaeological investigations, the recovery, protection, and preservation of archaeological artifacts and data from impacted sites, and publication of reports on archaeological investigations.

Archaeological Resources Protection Act of 1979

The Archaeological Resources Protection Act of 1979 (ARPA) was passed in response to a 1974 decision by the Ninth Circuit of the United States Court of Appeals. In United States v. Ben Diaz (1974), the Court found that the definitions in the Antiquities Act of 1906 were "unconstitutionally vague" (United States. Congress. House. Committee on Interior and Insular Affairs 1979). ARPA was passed to correct deficiencies in the Antiquities Act and "to secure ... the protection of archaeological resources and sites which are on public lands and Indian lands, and to foster increased cooperation and exchange of information between governmental authorities, the professional archaeological community, and private individuals" (Archaeological 
Resources Protection Act 1979). Section 9 of the law makes it illegal to share information about the nature and location of archaeological resources with the public (ibid). The Act has also been used to prosecute people who excavate artifacts on private land and transport them across state lines (Hicks 1997). Title 16, Chapter 1B, §470ee, Subsection (c) states "No person may sell, purchase, exchange, transport, receive, or offer to sell, purchase, or exchange, in interstate or foreign commerce, any archaeological resource excavated, removed, sold, purchased, exchanged, transported, or received in violation of any provision, rule, regulation, ordinance, or permit in effect under State or local law" (United States Code. 2016a).

\section{Recent Changes Impacting These Laws}

In 2014, portions of the preservation laws pertaining to the National Park Service (NPS) were reorganized and placed into a new title of the U.S. Code [Title 54]. It follows the policy, intent, and purpose of the original laws, but improves the organization of the Code by eliminating obsolete provisions, clarifying confusing provisions, settling inconsistencies and correcting technical errors (Office of Law Revision Counsel). Information on the confidentiality of archaeological sites can be found in two sections of the newly-enacted title. Title 54, Subtitle I, Division A, Chapter 1007, Subchapter I, §100707 Confidentiality of information states:
"Information concerning the nature and specific location of a [National Park Service] System resource that is endangered, threatened, rare, or commercially valuable, of mineral or paleontological objects within System units, or of objects of cultural patrimony within System units, may be withheld from the public in response to a request under section 552 of title 5" (Enactment of Title 54 2014).

Section 552 of Title 5 is the part of the U.S. Code that delineates the Freedom of Information Act. Title 54, Subtitle III, Division A, Subdivision 6, Chapter 3071, $\$ 307103$, which deals with access to information, states that agency heads and other public officials "shall withhold from disclosure to the public information about the location, character, or ownership of a historic property" (ibid.) if it could lead to trespass, or harm or impede use of sites for religious reasons.

The Archaeological Resources Protection Act, which was not impacted by the passage of Title 54, also deals with the confidentiality of archaeological resource locations. Title 16, Chapter 1B, $\$ 470 \mathrm{hh}$ of the U.S. Code states:

\footnotetext{
"Information concerning the nature and location of any archaeological resource for which the excavation or removal requires a permit or other permission under this chapter or under any other provision of Federal law may not be made available to the public under subchapter II of chapter 5 of title 5 or under any other provision of law" (United States Code 2016b).
}

All states also have laws protecting archaeological sites. Table 1, which was compiled by examining state laws and statutes available online, provides information on all existing state laws protecting archaeological sites and their locations. It provides information on whether a state has a law protecting archaeological sites, gives the legal citation to find the code, whether site locations are confidential, and a citation to the code protecting site locations. The laws vary from state to state. Some state archaeological protection laws include a clause protecting the locations of sites (e.g., Vermont, West Virginia and Wisconsin), while other states exempt release of information on archaeological sites in their public record or Freedom of Information (FOIA) laws (e.g., Arkansas, California, Michigan and Nebraska). In cases where 
confidentiality of archaeological sites is not mentioned in either the state archaeological protection laws or the open records laws, the FOIA laws contain clauses saying that information protected by Federal or other statutes is exempt from public release (e.g., Connecticut, New Jersey, and Oklahoma).

Legal protection for locations of archaeological resources and sites means that the reports of archaeological and cultural resource studies submitted to state archaeologists are not publicly available. Some libraries may have cultural resource studies and reports on archaeological work that were made available through Federal and state depository programs, but these reports are generally summaries of findings, and do not contain detailed site locations, such as geographic coordinates or section, township and range information. The Interior Department's standards and guidelines for archaeology and historic preservation include information on professional qualification standards for archaeologists (United States. National Park Service 1997). Most state archaeologist's offices require that people accessing detailed cultural resource studies or GIS data on archaeological sites meet the Secretary of the Interior's standards.

\section{Cave Protection Laws}

There are a number of reasons caves are protected in the United States, including preservation of speleothems, conservation of cave life, the need to protect cave visitors and the need to protect private property owners from liability (Mulvey 2000). Caves contain valuable mineral and rock formations, are home to a variety of life forms, including endangered species, and can be dangerous if visitors are unprepared. Karst formations, which are associated with caves, are important sources of water for public use. Finally, there are liability issues, for both landowners and, possibly, librarians.

A search in a newspaper database for articles on damage to caves (cave* and vandal* and damage*) finds articles on cave vandalism in newspapers published in many areas of the United States, from Virginia to California (Access World News 2016). In 1995, cave vandals stole over 800 pounds of speleothems (cave minerals and formations) from Crystal Cave (also known as Floyd Collins Crystal Cave), part of Mammoth Cave National Park (Mead 1996) and sold them to rock and mineral shops near the Park for about \$1.00 a pound (Nims and Foster 1995). Brad McDougal, one of the rangers who investigated the Crystal Cave vandalism and theft, described the damage as "wholesale mining" (ibid., 13). The vandals were caught and convicted for the crimes of destruction and theft of government property, which carried harsher sentences than the crime of cave vandalism. They were sentenced to Federal prison and community service (Associated Press 1996). Despite causing over \$250,000 in damage, their sentences did not include restitution (ibid.). The National Park Service's interpretive tours of Crystal Cave were discontinued because of the vandalism (Nims and Foster 1995). Work to repair the damage is proceeding, but it is a very exact, complicated process that will take time (Hildreth-Werker and others 2010; United States. National Park Service 2010).

Caves are homes to a wide variety of life forms, including microbes (Barton 2006), invertebrates, such as cave shrimp and spiders, and vertebrates, such as salamanders and bats (Hobbs 2005). Some of these species are threatened or endangered. In 1987, vandals killed endangered Indiana bats in Thornhill Cave in Kentucky (United States. Congress. Senate. Committee on Energy and Natural Resources 1988); the vandals were never caught.

The appearance and spread of white-nose syndrome in bats has resulted in the closure of many caves and mines in the United States (National Speleological Society 2015). White-nose syndrome is a disease caused by the fungus Pseudogymnoascus 
destructans (formerly called Geomyces destructans), which grows on the skin, muzzle, ears and wings of bats hibernating in caves (Rogall and Verant 2012). It was first described by biologists conducting surveys of hibernating bats in New York during the winter of 2006-2007, although cavers had photographed bats with the disease the previous year (Blehert et. al. 2011). The disease was probably introduced from Europe by people visiting show caves in New York (ibid.). Since then, the disease has spread north into Canada, south to Mississippi and west to Oklahoma (Heffernan 2015); in March, 2016 it was detected in Washington State (Washington State Department of Fish and Wildlife 2016). One study estimating bat populations before and after the emergence of white-nose syndrome indicates that the mortality rate of infected bats is over $80 \%$ (Turner, Reeder, and Coleman 2011). According to the national white-nose syndrome plan (United States. Fish and Wildlife Service 2011), the decrease in bat population could lead to an increase in the numbers of insect pests, resulting in damage to agricultural crops and forests. This could lead to increased pesticide use for insect control. Loss of bats could also increase public health risks, either through contact with pesticides or outbreaks of insect-borne diseases, such as the Zika virus. The report also states that cave and karst ecosystems could be disrupted by the loss of bat guano, a major source of nutrients for other cave life forms.

Caves may not be the safest place for unsuspecting, unprepared and inexperienced visitors, even if they have guides. In late May, 2016, 19 people, including 13 Clemson University college students, 4 tour guides and 2 police officers who tried to rescue the group, escaped a flooded Kentucky cave by wading through neck-deep water (Galofaro and Schreiner 2016). Sometimes, cave visitors are not so lucky. Crystal Cave was originally named Floyd Collins Crystal Cave for Floyd Collins, a cave explorer who became trapped and died in the cave in 1925 (United States. National Park Service 2016). It was later added to Mammoth Cave National Park. During the Midwest floods of 1993, a camp counselor and 5 children on an outing from a St. Louis-area boy's home died in a flooded cave (Edmonds 1993). The National Speleological Society tracks caving accidents and provides an annual summary of reported accidents (National Speleological Society 2016).

Karst formations, which are associated with caves, are important sources of groundwater. A public water-supply well in a karst aquifer near Tampa, Florida that has historically tested positive for coliform and fecal bacteria also tested positive for chemical pollutants, such as nitrates, volatile organic compounds, pesticides and arsenic (Jagucki and others 2009). In 2000, 17 percent of groundwater withdrawals for public water supplies in the United States came from carbonate (karst) aquifers (Maupin and Barber 2005).

\section{Cave Resources Protection Act}

Caves on Federal land are protected by the Cave Resources Protection Act (United States Code 2016c). The Act was originally proposed to Congress in 1985 by caving groups, who were concerned that vandalism, commercial exploitation, and overuse of caves by recreational groups were damaging caves' natural and cultural resources (Siehl 1985). The proposed law was analyzed in a Congressional Research Service report that year (ibid.), but was not formally introduced in Congress until April 7, 1987, when it was simultaneously proposed in the House of Representatives (United States. Congress. House 1987), and the Senate (United States. Congress. Senate 1987). After committee hearings were held in both the House and Senate, the House version, with a Senate amendment, was passed by Congress and signed into law November 18, 1988 (Federal Cave Resources Protection Act 1988). It was incorporated into Title 16 of 
the U.S. Code (United States Code 2016c). Title 16, Chapter 63, §4304 protects information about cave locations on Federal Lands:

\begin{abstract}
"Information concerning the specific location of any significant cave may not be made available to the public under section 552 of title 5 unless the Secretary determines that disclosure of such information would further the purposes of this chapter and would not create a substantial risk of harm, theft, or destruction of such cave" (ibid.).
\end{abstract}

Title 16 provides some exceptions; information can be released to Federal and State agencies and people at educational and research institutions who submit a written request for cave locations that includes information about the site or area of interest and reasons for the request. Requestors must also ensure that the information provided will remain confidential and the cave resources will be protected (ibid.). The U.S. Board on Geographic Names removed cave locations from its Geographic Names Information System [GNIS] after the passage of the Cave Resources Protection Act (United States. Board on Geographic Names 2014). The U.S. Geological Survey discontinued showing cave locations on topographic maps at the same time (GNIS is used as the basis for place names on maps).

\title{
State-level Cave Protection Laws
}

Some states also have cave protection laws (Atz 2014). Table 2 provides information on existing state cave protection laws, including a citation to the code and whether cave locations are confidential. For the most part, state cave protection laws make it illegal to collect cave minerals and formations, fauna and flora, and archaeological specimens, and to damage gates and locks that are placed on caves to protect them. Some state cave laws include clauses making it illegal to dump chemicals, refuse and garbage in caves and sinkholes to protect groundwater. Additionally, some state laws limit liability of landowners with caves on their property. Nims and Foster $(1995,15)$ state that one of the best means of protecting caves is secrecy. Unfortunately, only three states, Hawai'i, Maryland and Virginia, protect the locations of caves. In Hawai'i, the Cave Protection Law requires confidentiality of cave locations. The Freedom of Information laws in Maryland and Virginia specifically exempt cave locations from public release. Librarians can use the information in Table 2 to learn about the cave laws in their states. In addition to legal protections, there are other reasons why librarians might have concerns about providing information on cave locations, including the fact that caves may be found on private land and professional liability.

\section{Liability Issues}

Many of the cave protection laws deal with caves on public land, but caves can also be found on private land (Mulvey 2000). Landowners have been sued when cave visitors were injured or died in caves on private land (Tennessee Court of Appeals 2001; Nebraska Supreme Court 1992). Some states' cave protection laws include clauses limiting landowner liability (Atz 2014), while other states' recreation laws limit landowner liability (Wright, Kaiser and Nicholls 2002). The National Speleological Society's Guide to Responsible Caving states that people visiting caves should ask for permission from landowners before venturing into caves on private land and comply with the landowners' instructions and requests (Jones 2009). 
There could also be liability issues for librarians. If a librarian gave out information about the location of a cave where people subsequently died, could the librarian be held liable? Similarly, if a librarian gave someone the location of an archaeological site or cave that was vandalized, could they be held liable? Healey $(2008,76)$ states that librarians cannot "assume responsibility for how the information they provide is used." In other words, a librarian who gives information on the location of an archaeological site or cave probably cannot be held legally liable for the destruction of an archaeological site or cave by looters or vandals or someone's death in a cave. Carson (2006) states that there has never been a legal case where a librarian was sued for providing superseded materials or providing incorrect or incomplete information. He also points out that some states have laws limiting public employee's liability for providing information. Healy $(2008,81)$ states that librarians could be held liable if they provide incomplete or incorrect information while acting as paid information providers. While librarians probably could not be held legally liable for what happens if they provide information about the location of archaeological sites or caves, many librarians would likely feel morally responsible if they found that information they had provided resulted in damage to an archaeological site or cave, or lead to someone's death.

\section{Proposed Reference Policy for Librarians or Library Staff}

The laws regarding access to locations of archaeological sites and caves were developed to guide the type of information Federal and state agency employees can give to the public, but the legal and other issues described above should also inform our work as geospatial information librarians. Many libraries have policies on how they will answer questions involving requests for medical, legal, business and tax information (Brumley 2006, 193-194). Libraries generally provide definitions, refer people to print or online resources, and encourage them to consult professionals, but they do not give medical, legal, business or tax advice, help library users file their taxes or fill out other types of online forms. They also weed older reference materials on these topics to ensure that library users are consulting current materials that are appropriate to their needs. Unlike reference librarians, map and geospatial information librarians do not weed older materials dealing with their local area, because they are useful for historical, genealogical and potentially other research.

Librarians assigned to work with geospatial information are often consulted when people request location information. As a result, they should consider developing a policy on how they will answer questions about the locations of archaeological sites and caves based on their library's policies on answering medical, legal, business and tax questions. This policy should be documented and shared with colleagues. Librarians at several map and geology collections were consulted to determine whether they had policies about giving locations of archaeological sites and caves. The Library of Congress states that they do not restrict "access to materials in our collections or information depicted on maps. If a researcher is interested in the material, we serve the material except in conditions where access may be restricted by the United States Government." They also direct people to the historic topographic maps that are available through TopoView, which may contain sensitive locations (Redmond 2016).

Several other map and geology librarians were queried to determine whether they had policies about providing information about the location of caves and archaeological sites. One librarian indicated that he referred questions on archaeological sites to the state archaeologist (Parsons 2016). Jim Coombs at the Meyer Library at Missouri State University stated that their collection has a set of cave maps that 
circulate, but the maps do not contain the cave's locations. Since he does not know their locations, he does not provide that information (Coombs 2016). Marie Dvorzak at the C.K. Leith Library of Geology and Geophysics at the University of Wisconsin stated that she does not provide information on cave locations (Dvorzak 2016). Several other librarians who responded stated that they did not have a policy on providing locations of archaeological sites or caves. One librarian indicated that she would have to develop such a policy because she had found an uncataloged map in her university's collection that includes hand-written locations of archaeological sites.

Tom Emerson, Illinois State Archaeologist, was consulted for guidance on how librarians should respond to requests for locations of archaeological sites and Indian mounds. He stated that it is unlikely that librarians would have information on sites that are not publicly accessible. He also suggested that librarians should direct people requesting such information to their state archaeologist's office or historic preservation agency (Emerson 2016). The people at these agencies can assess the requestor's credentials to see if they meet the criteria of the Department of the Interior's Professional Qualification Standards (United States. National Park Service 1997), have a legitimate need for information on the location of such sites and determine whether to provide the information to the requestor. Links to state archaeologists' websites can be found on the National Association of State Archaeologists website (http://archaeology.uiowa.edu/national-association-state-archaeologists). He also suggested that librarians direct people seeking information about archaeological sites to publicly accessible, interpreted sites in state or national parks.

Librarians should refer people looking for cave locations to their state's geological or natural history surveys. State geological surveys are linked to the American Association of State Geologists website (http://www.stategeologists.org/); there is no comparable organization for natural history surveys. The surveys can determine whether the requestor has a valid need for cave locations and either provide the location or direct the requestor to another source for the information. They are probably also aware of cave closures for other reasons, such as white-nose syndrome, flooding or other hazards. Alternatively, the requestor could be referred to a local Grotto of the National Speleological Society (National Speleological Society 2007), which can offer potential cavers the opportunity to meet other, experienced, spelunkers and invite them on a visit to a local cave. Local Grottos are also aware of issues that might result in cave closures.

\section{Conclusions}

Librarians are strong advocates of open access, from journal articles to data. At the same time, they are also advocates for preservation. Map and geospatial librarians actively collect and preserve maps and other materials that deal with their local areas. However, there are valid reasons for restricting access to some information, such as the locations of archaeological sites and caves. Archaeological sites contain artifacts that can be used to interpret and reconstruct the way of life, culture and history of an area's past inhabitants as well as the area's natural history. Once they are plundered by artifact thieves, the sites and artifacts are useless for scientific research. Caves contain valuable mineral specimens, fragile, important ecosystems and can be dangerous if visitors are inexperienced or unprepared. Karst terrain, which is associated with caves, is also an important source of drinking water in many areas of the United States. In addition, many caves and some archaeological sites, especially Indian mounds, are located on private property, which are protected by trespassing laws. Map librarians usually do not have the resources to help determine whether the site is on public or private land, or the 
name of a landowner and their contact information so that potential visitors can get permission to visit a site. Librarians also do not have a way to judge whether a requestor is simply a curious visitor who wants to visit a site for intellectual enlightenment or a vandal intent on plundering artifacts or mineral specimens for personal gain. Unfortunately, this means that when asked for information on the locations of archaeological sites and caves, librarians must take the advice of the X-Files' Fox Mulder: "Trust No One."

Geospatial information librarians need to become aware of the archaeological and cave protection laws in their states. Researching Illinois' laws regarding archaeological sites and caves revealed that cave locations in both Illinois and Missouri are not available from state agencies. To avoid open records requests for cave locations, the state agencies that might have this information have abrogated responsibility for maintaining information on cave locations to the Illinois Speleological Survey and the Missouri Speleological Survey, respectively, which are projects of the National Speleological Society.

While archaeological sites are protected in all states, some states' archaeological protection and open records laws do not contain specific language exempting archaeological site locations from open records requests, and instead include vague statements indicating that information protected by law is confidential. Of the 28 states that have laws protecting caves, only 3 states protect their locations. Librarians need to learn about the laws in their states and encourage their state agencies and legislators to strengthen their states' open records laws to exempt the locations of archaeological sites and caves from public release.

Librarians should also consider taking steps to secure reference and other library materials, such as gazetteers, manuscript or historic maps, and books on caves, which may contain detailed locations of archaeological sites and caves. The questions at the beginning of this article were all asked of this author. Unfortunately, the author has also seen gazetteers and books on caves disappear from library collections after people asked for locations of ruins and caves. People who abscond with reference books containing the locations of ruins and caves probably do not have the best intentions in mind during their visits to archaeological sites and caves. Ideally, library resources with the locations of caves and ruins should only be available for in-library use, and not circulate or be sent out on Interlibrary Loan. Librarians might also want to consider retaining a user's ID or checking materials with archaeological and cave locations out using their library's online circulation system to ensure that the resource is returned after use. They should also consider consulting their state archaeologist's office and geological or natural history surveys before digitizing older materials, such as explorer's accounts, surveys, field notebooks and out-of-print cave books that contain locations of archaeological sites, ruins, Indian mounds and caves.

Finally, geospatial information librarians need to develop and document policies on answering questions about the locations of archaeological sites and caves. People asking for the location of archaeological sites, ruins and Indian mounds should be referred to government agencies such as the National Park Service, or state archaeological surveys or historic preservation offices. People requesting information on cave locations should be referred to the U.S. Geological Survey, state geological or natural history surveys or caving organizations, such as the National Speleological Society or the local NSS grotto. The government agencies can evaluate the requestor's need and credentials and either provide the information or explain why the information is not available. Librarians might also want to develop a list of, or website with links to, 
interpreted, publicly accessible archaeological sites and caves to provide to people requesting such information.

Acknowledgments

The author would like to thank Jeff Hancks, Head of Archives at Western Illinois University for reading and commenting on this article; Anne Huber and Mark Yacucci at the Illinois State Geological Survey for providing insight on access to cave location information in Illinois; Dr. Thomas Emerson, Director of the Illinois State Archaeological Survey, for insight on Illinois laws regarding archaeological sites and the anonymous reviewers who provided input on this article.

\section{REFERENCES}

Access World News. 2016. Online Search for Cave* and vandal* and damage*. July 12, 2016. NewsBank.

Archaeological Resources Protection Act of 1979. Public Law 96-95. 93 Stat. 721-728.

October 31, 1979. https://www.gpo.gov/fdsys/pkg/STATUTE-

93/pdf/STATUTE-93-Pg721.pdf accessed July 1, 2016.

Archeological and Historic Preservation Act of 1974. An Act to amend the Act of June 27, 1960 (74 Stat. 220), relating to the preservation of historical and archeological data. Public Law 93-291 (S. 514). Friday, May 24, 1974. Public Law 93-291. 88 Stat. 174. https://www.gpo.gov/fdsys/pkg/STATUTE88/pdf/STATUTE-88-Pg174.pdf accessed July 12, 2016.

Associated Press. 1996. Men to go to prison for cave vandalism. Lexington HeraldLeader (KY) May 23, C1. Access World News, accessed July 14, 2016.

Atz, Aaron. 2014. State Cave Protection Laws: State-by-State. Huntsville, AL: National Speleological Society.

https://caves.org/committee/conservation/pdf/StateCaveProtectionLaws.pdf accessed July 14, 2016.

Barton, Hazel. 2006. Introduction to cave microbiology: A review for the non-specialist. Journal of cave and karst studies 68(2): 43-54.

Benderson, Judith. 2015. Native American artifacts: The Archaeological Resources Protection Act and the Native American Graves Protection and Repatriation Act. Washington, D.C.: U.S. Department of Justice, Offices of the United States Attorneys. https://www.justice.gov/usao/priority-areas/indian-country/nativeamerican-artifacts.

Blehert, David, Jeffrey Lorch, Anne Ballmann, Paul Cryan and Carol Meteyer. 2011. Bat white-nose syndrome in North America. Microbe 6(6): 267-273.

Brumley, Rebecca, ed. 2006. The reference librarian's policies, forms, guidelines, and procedures handbook. New York: Neal-Schuman Publishers.

Carson, Bryan. 2006. Legally speaking -- do librarians need liability insurance? Against the grain 18(5): article 28. http://docs.lib.purdue.edu/atg/vol18/iss5/28 accessed July 8, 2016.

Coombs, Jim. 2016. Personal communication. June 23, 2016.

Davis, Hester. 1972. The crisis in American archaeology. Science 175(4019): 267-272.

Dilsaver, Lary M., ed. 1994. America's National Park system: The critical documents. Lanham, Md.: Rowan \& Littlefield Publishers.

Dunkel, Tom. 1992. A nation's heritage at risk. Insight on the News February 17, 12-16, 36-38.

Dvorzak, Marie. 2016. Personal communication. June 23, 2016.

Edmonds, Patricia. 1993. Cave expedition takes deadly turn in St. Louis. USA Today, July 26, 3A. 
Ellis, Linda, ed. 2000. Archaeological method and theory: An encyclopedia, xv. New York: Garland Publishing.

Emerson, Thomas. 2016. Personal communication. June 26, 2016.

Enactment of Title 54: National Park Service and related programs. P.L. 113-287. December 19, 2014. Washington, D.C.: Government Printing Office. http://purl.fdlp.gov/GPO/gpo56853 accessed July 12, 2016

Federal Cave Resources Protection Act of 1987. 1988. P.L. 100-691. 102 Stat. 45464551. https://www.gpo.gov/fdsys/pkg/STATUTE-102/pdf/STATUTE-102Pg4546.pdf accessed July 12, 2016.

Fewkes, J. Walter. 1910. Reports of the superintendent of Mesa Verde National Park and J. Walter Fewkes, in charge of excavation and repair of ruins. In Reports of the Department of the Interior for the fiscal year ended June 30, 1909, Volume I, Secretary of the Interior. Bureaus, except Office of Indian Affairs, eleemosynary institutions, national parks and reservations. Serial Set volume number 5746, 61st Congress, 2nd Session, H. Doc. 107, pt. 1, v.1: 486-487.

Galofaro, Claire and Bruce Schreiner. 2016. 19 trapped people wade out of Kentucky cave. St. Louis Post-Dispatch May 27, A6. Retrieved from NewsBank, July 1, 2016.

Healey, Paul. 2008. Professional liability issues for librarians and information professionals. New York: Neal-Schuman Publishers, Inc.

Heffernan, Lindsey. 2015. Bat white nose syndrome: Occurrence by county/district or portions thereof $11 / 19 / 2015$. https://www.whitenosesyndrome.org/resources/map accessed July 8, 2016.

Hicks, Robert D. 1997. Time crime: Protecting the past for future generations. FBI law enforcement bulletin 66(7): 1-7.

Hildreth-Werker, Val, Jim Werker, Rick Olson and Doug Soroka. 2010. Floyd Collins Crystal Cave: repair of vandalized gypsum speleothems. NSS News 68(3): 1518.

Historic Sites Act. 1935. P.L. 74-292. 49 Stat. 666-668. August 21, 1935. http://www.loc.gov/law/help/statutes-at-large/74th-congress/c74.pdf accessed July 12, 2016.

Hobbs, Horton H., III. 2005. Diversity patterns in the United States. In Encyclopedia of caves, ed. David Culver and William White, 170-183. Oxford: ElsevierAcademic Press.

Jagucki, Martha, Brian Katz, Christy Crandall and Sandra Eberts. 2009. Assessing the vulnerability of public-supply wells to contamination: Floridan Aquifer system near Tampa, Florida. U.S. Geological Survey Fact Sheet 2009-3062. Reston, Va.: U.S. Geological Survey.

Jones, Cheryl. 2009. A guide to responsible caving. Huntsville, AL: National Speleological Society. https://caves.org/brochure/NSS\%20Guide\%20Color\%20809.pdf accessed July 14,2016

Lee, Ronald. 2001. The story of the Antiquities Act. National Park Service. http://www.nps.gov/archeology/PUBS/LEE/Index.htm accessed July 12, 2016.

Lipe, William D. 2002. Public benefits of archaeological research. In Public benefits of archaeology, ed. Barbara J. Little, 20-28. Gainesville: University Press of Florida.

Maupin, Molly and Nancy Barber. 2005. Estimated withdrawals from principal aquifers in the United States, 2000. U.S. Geological Survey Circular 1279. Reston, Va.: U.S. Geological Survey. 
McManamon, Francis. 2000. Archeological and Historic Preservation Act (AHPA). In Archaeological method and theory: an encyclopedia, ed. Linda Ellis, 60-62. New York: Garland Publishing.

Mead, Andy. 1996. Crystal clear evidence: Three men facing prison for thefts, defacing cave. Lexington Herald-Leader (KY) March 1, B1.

Mignon, Molly R. 1993. Dictionary of concepts in archaeology. Westport, Conn.: Greenwood Press.

Mulvey, Bridget. 2000. Cave confidentiality. Geotimes 45(9): 8.

National Historic Preservation Act of 1966. To establish a program for the preservation of additional historic properties throughout the Nation, and for other purposes. P.L. 89-665. 80 Stat. 915-919. https://www.gpo.gov/fdsys/pkg/STATUTE80/pdf/STATUTE-80-Pg915.pdf accessed July 12, 2016.

National Speleological Society. 2007. Find a grotto. Huntsville, AL: National Speleological Society. http://www.nssio.org/Find_Grotto.cfm accessed July 14, 2016.

National Speleological Society. 2015. Cave closures. Huntsville, AL: National Speleological Society. https://caves.org/WNS/Cave_Closures.shtml accessed July 14, 2016.

National Speleological Society. 2016. American caving accidents. Huntsville, AL: National Speleological Society. https://caves.org/pub/aca/index.shtml accessed July 14, 2016.

Nebraska Supreme Court. 1992. David L. Terry v. William R. Metzger. 491 N.W.2d 50.

Nims, Peggy and Debbie Foster. 1995. American caves objects of beauty become victims of vandalism: The destruction of our national treasures. American caves (Spring-Summer): 12-19.

Office of Law Revision Counsel. Positive Law Codification. Washington, D.C.: Office of Law Revision Counsel.

http://uscode.house.gov/codification/legislation.shtml. Accessed: July 12, 2016.

Parsons, Matthew. 2016. Personal Communication.

PBS/WGBH Boston. Antiques Roadshow appraisals archive for tribal arts. Accessed September 9, 2016. http://www.pbs.org/wgbh/roadshow/appraisals.

Prudden, T. Mitchell. 1903. The prehistoric ruins of the San Juan Watershed in Utah, Arizona, Colorado and New Mexico. American Anthropologist (n.s.) 5 (AprilJune): 224-288.

Redmond, Edward. 2016. Personal Communication.

Rogall, Gail and Michelle Verant. 2012. White-Nose Syndrome in Bats: U.S. Geological Survey Updates. U.S. Geological Survey Fact Sheet 2012-3076. Reston, VA: U.S. Geological Survey.

Sharp, Kathleen. 2015. The Rescue Mission. Smithsonian 46(7): 40-49.

Siehl, George. 1985. The Federal Cave Resources Protection Act: A Review of a Proposed Bill. Washington, D.C.: Congressional Research Service, Library of Congress.

Tennessee Court of Appeals. 2002. Karen Bishop, et al. v. Helen G. Beckner. 109 S.W.3d 725, 728 .

Texas Administrative Code. 2013. Title 13. Part 2. Chapter 26. Subchapter C. Rule $\$ 26.16$ Reports Relating to Archeological Permits.

http://texreg.sos.state.tx.us/public/readtac\$ext.TacPage?sl=R\&app=9\&p_dir=\&p _rloc $=\& p \_t l o c=\& p \_p l o c=\& p g=1 \& p \_t a c=\& t i=13 \& p t=2 \& c h=26 \& r l=16$ accessed July 19, 2016. 
Turner, Gregory, DeeAnn Reeder and Jeremy Coleman. 2011. A five-year assessment of mortality and geographic spread of white-nose syndrome in North American bats and a look to the future. Bat research news 52(2): 13-27.

United States Code. 2016a. Archaeological Resources Protection Act. Title 16 U.S.Code, Chapter 1B, §470ee, Subsection (c). http://uscode.house.gov/view.xhtml?req=granuleid:USC-prelim-title16section470ee\&num $=0 \&$ edition $=$ prelim

United States Code. 2016b. Archaeological Resources Protection Act. Title 16 U.S.Code, Chapter 1B, §470aa-470mm. http://uscode.house.gov/view.xhtml?path=/prelim@title16/chapter1B\&edition=p relim accessed July 14, 2016.

United States Code. 2016c. Federal Cave Resources Protection Act. Title 16 U.S.Code, Chapter 63, §4301-4310. http://uscode.house.gov/browse/prelim@title16/chapter63\&edition=prelim accessed July 12, 2016.

United States. Board on Geographic Names. 2014. Frequently asked questions: Why are there no entries for caves in the GNIS Database? http://geonames.usgs.gov/domestic/faqs.htm accessed July 12, 2016.

United States. Congress. House. 1987. Federal Cave Resources Protection Act of 1988. 1st sess., H.R.1975. Washington, D.C.: United States Congress. http://hdl.loc.gov/loc.uscongress/legislation.100hr1975 accessed July 12, 2016.

United States. Congress. House. Committee on Interior and Insular Affairs. 1979. Protecting Archaeological Resources Owned By The United States, and for Other Purposes: Report To Accompany H.R. 1825. House Report 96-311, 96th Congress, 1st Session. Washington, D.C.: Government Printing Office.

United States. Congress. House. Committee on Public Lands. 1935. Preservation of historic American sites, buildings, objects, and antiquities of national significance: Hearing on H.R. 6670 and H.R. 6734. 74th Congress, 1st Session. Washington, D.C.: Government Printing Office. (Statement of Harold L. Ickes, Secretary of the Interior).

United States. Congress. Senate. 1987. Federal Cave Resources Protection Act of 1987. 1st Sess., S.927. Washington, D.C.: United States Congress. http://hdl.loc.gov/loc.uscongress/legislation.100s927 accessed July 12, 2016.

United States. Congress. Senate. Committee on Energy and Natural Resources. 1988. Federal Cave Resources Protection Act and restriction of dams in parks and monuments: hearing before the Subcommittee on Public Lands, National Parks, and Forests of the Committee on Energy and Natural Resources. 100th Congress, 2nd session, on S. 927/H.R. 1975 to protect cave resources on Federal lands, and for other purposes, H.R. 1173 to provide for certain restrictions on the use of lands within boundaries of national parks and monuments, June 16, 1988. Washington, D.C.: U.S. Government Printing Office.

United States. Federal Geographic Data Committee. Homeland Security Working Group. 2005. Guidelines for Providing Appropriate Access to Geospatial Data in Response to Security Concerns. Reston, VA: Federal Geographic Data Committee. http://www.fgdc.gov/policyandplanning/Access\%20Guidelines.pdf accessed July 12, 2016.

United States. Fish and Wildlife Service. 2011. A National Plan for Assisting States, Federal Agencies, and Tribes in Managing White-Nose Syndrome in Bats. Hadley, MA: U.S. Fish and Wildlife Service. 
https://www.whitenosesyndrome.org/sites/default/files/whitenose_syndrome_national_plan_may_2011_0.pdf accessed July 12, 2016.

United States. Geological Survey. 1987. The National Gazetteer of the United States of America: Arizona. [Washington, D.C.]: U.S. Government Printing Office.

United States. National Park Service. 1997. The Secretary of the Interior's Historic Preservation Professional Qualification Standards. Federal Register 62 FR 33708, p. 33708 -33723. https://www.federalregister.gov/articles/1997/06/20/9716168/the-secretary-of-the-interiors-historic-preservation-professionalqualification-standards accessed July 14, 2016.

United States. National Park Service. 2006. Federal historic preservation laws: the official compilation of U.S. cultural heritage statutes. Washington, D.C.: Cultural Resources, National Park Service, U.S. Department of the Interior. http://purl.access.gpo.gov/GPO/LPS110183 accessed July 12, 2016.

United States. National Park Service. 2010. Restoration experts work at Crystal Cave. Press Release. Mammoth Cave, KY: National Park Service. https://www.nps.gov/maca/learn/news/crystal-cave-restoration.htm accessed July 12, 2016.

United States. National Park Service. 2016. I'm trapped and trapped for life! [Story of Floyd Collins]. https://www.nps.gov/maca/learn/historyculture/trapped.htm accessed July 1, 2016.

United States v. Ben Diaz. 1974. 499 F. 2d 113. 9th Circuit Court of Appeals.

Washington Department of Fish and Wildlife. 2016. Wildlife health: White nose syndrome. http://wdfw.wa.gov/conservation/health/wns/ accessed July 8, 2016.

Wright, Brett A., Ronald A. Kaiser and Sarah Nicholls. 2002. Rural landowner liability for recreational injuries: Myths, perceptions, and realities. Journal of soil and water conservation 57(3): 183-191.

Table 1. State archaeological protection laws in the United States showing laws protecting archaeological sites and information about the location of archaeological sites.

Table 2. State cave protection laws in the United States showing laws protecting caves and whether cave locations are confidential. 
Table 1. State archaeological protection laws in the United States showing laws protecting archaeological sites and information about the location of archaeological sites.

\begin{tabular}{|c|c|c|c|c|}
\hline State & $\begin{array}{l}\text { Archaeolo- } \\
\text { gical Site } \\
\text { Law? }\end{array}$ & $\begin{array}{l}\text { Code Protecting } \\
\text { Archaeological } \\
\text { Sites }\end{array}$ & $\begin{array}{l}\text { Locations } \\
\text { Confidential? }\end{array}$ & $\begin{array}{l}\text { Code Protecting } \\
\text { Site Locations? }\end{array}$ \\
\hline Alabama & Yes & $\begin{array}{l}\text { Alabama Code, } \\
\text { Title 41, Chapter } \\
3\end{array}$ & Yes & $\begin{array}{l}\text { Alabama Code } \\
\text { Title } 36, \S 36-12- \\
40 . \text { Exceptions to } \\
\text { open records law if } \\
\text { provided by statute }\end{array}$ \\
\hline Alaska & Yes & $\begin{array}{l}\text { Alaska Statutes, } \\
\text { Title } 41 \text {, } \\
\S 41.35 .200\end{array}$ & Yes & $\begin{array}{l}\text { Alaska Statutes, } \\
\text { Title Title } 40, \\
\$ 40.25 .120(a)(4) \\
\text { Exceptions to open } \\
\text { records law if } \\
\text { provided by statute }\end{array}$ \\
\hline Arizona & Yes & $\begin{array}{l}\text { Arizona Code } \\
\text { Title } 41, \text { Chapter } \\
4.1, \text { Article } 4 \\
\text { (also protects } \\
\text { fossils) }\end{array}$ & Yes & $\begin{array}{l}\text { Arizona Code Title } \\
39, \text { Chapter } 1 \text {, } \\
\text { Article } 2 \text {, Section } \\
125 \text { exempts } \\
\text { release of } \\
\text { archaeological } \\
\text { information }\end{array}$ \\
\hline Arkansas & Yes & $\begin{array}{l}\text { Arkansas Code, } \\
\text { Title 13, Chapter } \\
6 \text {, Subchapter 3-4 } \\
\text { protects artifacts }\end{array}$ & Yes & $\begin{array}{l}\text { Arkansas Code, } \\
\text { Title 25, Chapter } \\
\text { 19, Section } 105 \text {, } \\
\text { subsection b } 3 \\
\text { exempts } \\
\text { archaeological } \\
\text { records }\end{array}$ \\
\hline California & Yes & $\begin{array}{l}\text { California Public } \\
\text { Resources Code } \\
\text { Section 5097- } \\
\text { 5097.993 and } \\
\text { 5097.993- } \\
\text { 5097.994; Penal } \\
\text { Code, Part 1, Title } \\
\text { 14; Malicious } \\
\text { Mischief [594 - } \\
\text { 625c] }\end{array}$ & Yes & $\begin{array}{l}\text { California State } \\
\text { Government Code } \\
\text { Section } \$ 6254.10 \\
\text { exempts } \\
\text { archaeological } \\
\text { sites from } \\
\text { disclosure }\end{array}$ \\
\hline
\end{tabular}




\begin{tabular}{|c|c|c|c|c|}
\hline Colorado & Yes & $\begin{array}{l}\text { Colorado Revised } \\
\text { Statutes, } \$ 24-80- \\
401 \text { to } 411 ; \S 24- \\
80-1301-1305\end{array}$ & Yes & $\begin{array}{l}\text { Colorado Revised } \\
\text { Statutes, \$24-72- } \\
203 \text { (1) allows } \\
\text { exemptions to } \\
\text { public records } \\
\text { laws but does not } \\
\text { mention } \\
\text { archaeological } \\
\text { resources; Office } \\
\text { of Archaeology } \\
\text { and Historic } \\
\text { Preservation, } \\
\text { Publication \#1333 } \\
\text { (Dissemination of } \\
\text { Cultural Resource } \\
\text { Information: } \\
\text { Policy and } \\
\text { Procedures) } \\
\text { exempts cultural } \\
\text { resource } \\
\text { information from } \\
\text { public records law }\end{array}$ \\
\hline Connecticut & Yes & $\begin{array}{l}\text { General Statutes } \\
\text { of Connecticut } \\
\text { Title } 10 \text {, Chapter } \\
184 a, \S 10-390\end{array}$ & Yes & $\begin{array}{l}\text { Title } 1, \text { Chapter } \\
14, \S 1-210 \\
\text { Exceptions to open } \\
\text { records law if } \\
\text { provided by statute }\end{array}$ \\
\hline Delaware & Yes & $\begin{array}{l}\text { Delaware Code } \\
\text { Title 7, Chapter } \\
\text { 53, Subchapter II, }\end{array}$ & Yes & $\begin{array}{l}\text { Laws of Delaware, } \\
143^{\text {rd }} \text { General } \\
\text { Assembly, } 75 \\
\text { chapter } 153, \S 5314 \\
\text { Location of } \\
\text { archaeological } \\
\text { sites confidential }\end{array}$ \\
\hline $\begin{array}{l}\text { District of } \\
\text { Columbia }\end{array}$ & Yes & $\begin{array}{l}\text { US Federal Law } \\
\text { applies }\end{array}$ & & $\begin{array}{l}\text { US Federal Law } \\
\text { applies }\end{array}$ \\
\hline Florida & Yes & $\begin{array}{l}\text { Florida Statutes } \\
\text { Title XVIII, } \\
\text { Chapter } 267.13\end{array}$ & Yes & $\begin{array}{l}\text { Florida Statutes } \\
\text { Title XVIII, } \\
\text { Chapter 267.135 } \\
\text { Location of } \\
\text { archaeological } \\
\text { sites exempt from } \\
\text { disclosure }\end{array}$ \\
\hline Georgia & Yes & $\begin{array}{l}\text { Code of Georgia } \\
\S 12-3-52 ; \S 12-3- \\
54 \& \S 12-3-620- \\
622\end{array}$ & Yes & $\begin{array}{l}\text { Code of Georgia } \\
\S 50-18-72,(13) \\
\text { Records are } \\
\text { exempt if they } \\
\text { relate to the } \\
\text { location and }\end{array}$ \\
\hline
\end{tabular}




\begin{tabular}{|c|c|c|c|c|}
\hline & & & & $\begin{array}{l}\text { character of a } \\
\text { historic property }\end{array}$ \\
\hline Hawaii & Yes & $\begin{array}{l}\text { Hawaii Revised } \\
\text { Statutes Title 1, } \\
\text { Chapter } \$ 6 \mathrm{E}\end{array}$ & Yes & $\begin{array}{l}\text { Hawaii Revised } \\
\text { Statutes Title 1, } \\
\text { Chapter } \$ 6 \mathrm{E}-17 \\
\text { (B) archaeological } \\
\text { survey data will } \\
\text { not include } \\
\text { confidential } \\
\text { information; } \\
\text { Hawaii } \\
\text { Administrative } \\
\text { Rules } § 13 \text { - } 300 \text { - } \\
4 \text { exempts } \\
\text { disclosure of } \\
\text { archaeological } \\
\text { information }\end{array}$ \\
\hline Idaho & Yes & $\begin{array}{l}\text { Idaho Statutes, } \\
\text { Title 67, Chapter } \\
41,67-4119- \\
4122 ; \text { protects } \\
\text { archaeological } \\
\text { remains and } \\
\text { fossils }\end{array}$ & Yes & $\begin{array}{l}\text { Idaho Statutes, } \\
\text { Title Title } 74, \\
\text { Chapter } 1,74-108 . \\
\text { archaeological } \\
\text { records exempt }\end{array}$ \\
\hline Illinois & Yes & $\begin{array}{l}20 \text { Illinois } \\
\text { Compiled Statutes } \\
\S 3435 \& \S 3440\end{array}$ & Yes & $\begin{array}{l}20 \text { Illinois } \\
\text { Compiled Statutes } \\
\S 3435 / 10 \text { limits } \\
\text { access to records } \\
\text { on archaeological } \\
\text { sites }\end{array}$ \\
\hline Indiana & Yes & $\begin{array}{l}\text { Indiana Code, } \\
\text { Title 14, Article } \\
21\end{array}$ & Yes & $\begin{array}{l}\text { IC 14-21-1-32 } \\
\text { archaeological site } \\
\text { locations } \\
\text { confidential }\end{array}$ \\
\hline Iowa & Yes & $\begin{array}{l}\text { Iowa Code, Title } \\
\text { VII, §263B.10 } \\
\text { protects ancient } \\
\text { human remains; } \\
\text { Title XVI, } \$ 716.5\end{array}$ & Yes & $\begin{array}{l}\text { Iowa Code, Title } \\
\text { VII, 263B.10 deals } \\
\text { with } \\
\text { confidentiality of } \\
\text { archaeological } \\
\text { locations } \\
\text { Information }\end{array}$ \\
\hline Kansas & Yes & $\begin{array}{l}\text { Kansas Statutes } \\
\text { Annotated } \\
\text { Chapter 75, } \\
\text { Article 27, §75- } \\
\text { 2726; §75-2748; } \\
\S 74-5403\end{array}$ & Yes & $\begin{array}{l}\text { Kansas Statutes } \\
\text { Annotated Chapter } \\
75 \text {, Article 27, } \\
\text { \$75-2746b registry } \\
\text { of sites is } \\
\text { confidential }\end{array}$ \\
\hline
\end{tabular}




\begin{tabular}{|c|c|c|c|c|}
\hline Kentucky & Yes & $\begin{array}{l}\text { Kentucky Revised } \\
\text { Statutes Chapter } \\
164.705-\text { KRS } \\
164.735 ; \text { KRS } \\
164.990\end{array}$ & Yes & $\begin{array}{l}\text { Kentucky Revised } \\
\text { Statutes } 61.878 \\
\text { exempts } \\
\text { information } \\
\text { compiled for } \\
\text { scientific purposes }\end{array}$ \\
\hline Louisiana & Yes & $\begin{array}{l}\text { Louisiana Revised } \\
\text { Statutes Title 41, } \\
\S 1601-\S 1615\end{array}$ & Yes & $\begin{array}{l}\text { Louisiana Revised } \\
\text { Statutes Title 41, } \\
\$ 1609 \text { locations of } \\
\text { archeological sites } \\
\text { confidential }\end{array}$ \\
\hline Maine & Yes & $\begin{array}{l}\text { Maine Revised } \\
\text { Statutes Title 27, } \\
\S 371-378\end{array}$ & Yes & $\begin{array}{l}\text { Maine Revised } \\
\text { Statutes Title } 27, \S \\
377, \text { site locations } \\
\text { are protected }\end{array}$ \\
\hline Maryland & Yes & $\begin{array}{l}\text { Maryland Statutes } \\
\text { State Finance and } \\
\text { Procurement } \$ 5 A- \\
333-\S 5 A-346\end{array}$ & Yes & $\begin{array}{l}\text { Maryland } \\
\text { Annotated Code } \\
\text { article GGP, } \S 4- \\
350 \text { disclosure of } \\
\text { sites exempt }\end{array}$ \\
\hline Massachusetts & Yes & $\begin{array}{l}\text { Massachusetts } \\
\text { General Laws, } \\
\text { Part I, Title II, } \\
\text { Chapter 9, §26A - } \\
27\end{array}$ & Yes & $\begin{array}{l}\text { Massachusetts } \\
\text { General Laws, Part } \\
\text { I, Title Ii, Chapter } \\
\text { 9, Section 26A, } \\
\text { subsection (1) } \\
\text { inventory not } \\
\text { public record }\end{array}$ \\
\hline Michigan & Yes & $\begin{array}{l}\text { Michigan Natural } \\
\text { Resources and } \\
\text { Environmental } \\
\text { Protection Act, } \\
\text { Chapter } 324 \text {, Act } \\
451 \text { of } 1994 \text {, } \\
\$ 76102 \& \S 76106\end{array}$ & Yes & $\begin{array}{l}\text { Michigan Freedom } \\
\text { of Information Act } \\
\text { Exemptions, } \\
\text { Chapter } 15 \text {, Act } \\
442 \text { of } 1976, \\
\text { Section } 15.243, \\
\text { subsection o } \\
\text { exempts locations } \\
\text { of archaeological } \\
\text { sites }\end{array}$ \\
\hline Minnesota & Yes & $\begin{array}{l}\text { 2015 Minnesota } \\
\text { Statutes, Chapter } \\
\text { 138.31-138.42; } \\
\text { Chapter } 307.08 \\
\text { provides penalties } \\
\text { for damage \& } \\
\text { molestation of } \\
\text { human remains; } \\
\text { burials; } \\
\text { cemeteries }\end{array}$ & Yes & $\begin{array}{l}\text { 2015 Minnesota } \\
\text { Statutes, Chapter } \\
307.08, \\
\text { Subdivision } 11 \\
\text { protects } \\
\text { information about } \\
\text { burial site } \\
\text { locations; } 13.37 \\
\text { protects } \\
\text { information that } \\
\text { could jeopardize } \\
\text { the security of }\end{array}$ \\
\hline
\end{tabular}




\begin{tabular}{|c|c|c|c|c|}
\hline & & & & $\begin{array}{l}\text { property against } \\
\text { theft } \& \text { tampering }\end{array}$ \\
\hline Mississippi & Yes & $\begin{array}{l}\text { Mississippi Code, } \\
\text { Title 39, Chapter } \\
7, \S 39-7-29-\S \\
39-7-35\end{array}$ & Yes & $\begin{array}{l}\text { Mississippi Code, } \\
\text { Title 39, Chapter } \\
7, \S 39-7-41 \\
\text { archaeological } \\
\text { records exempt } \\
\text { from public access }\end{array}$ \\
\hline Missouri & Yes & $\begin{array}{l}\text { Missouri Revised } \\
\text { Statutes, Title } \\
\text { XII, Chapter 194, } \\
\text { Section 400-410 }\end{array}$ & Yes & $\begin{array}{l}\text { Missouri Revised } \\
\text { Statutes, Section } \\
610.021 .1 \text {, sub- } \\
\text { section (14) } \\
\text { exceptions to open } \\
\text { records law if } \\
\text { provided by } \\
\text { statute; Missouri } \\
\text { Cultural Resource } \\
\text { Inventory website } \\
\text { contains } \\
\text { information on } \\
\text { various } \\
\text { information } \\
\text { resources } \\
\text { available, some of } \\
\text { which are } \\
\text { restricted }\end{array}$ \\
\hline Montana & Yes & $\begin{array}{l}\text { Montana Code } \\
\text { Annotated, Title } \\
\text { 22, Chapter } 3 \text {, } \\
\text { Part } 8\end{array}$ & Yes & $\begin{array}{l}\text { Montana Code } \\
\text { Annotated, 22-3- } \\
807 \text { records are } \\
\text { exempt from } \\
\text { public disclosure }\end{array}$ \\
\hline Nebraska & Yes & $\begin{array}{l}\text { Nebraska Revised } \\
\text { Statutes, Chapter } \\
82 \text {, Sections } 501 \text { - } \\
510\end{array}$ & Yes & $\begin{array}{l}\text { Nebraska Revised } \\
\text { Statutes, 84- } \\
712.05 \text { (13) } \\
\text { archaeological \& } \\
\text { paleontological } \\
\text { records exempt } \\
\text { from public } \\
\text { disclosure }\end{array}$ \\
\hline Nevada & Yes & $\begin{array}{l}\text { Nevada Revised } \\
\text { Statutes Chapter } \\
383, \S 150-190\end{array}$ & Yes & $\begin{array}{l}\text { Nevada Revised } \\
\text { Statutes, } 239.010 \\
\text { could be } \\
\text { interpreted to say } \\
\text { that records are } \\
\text { confidential; }\end{array}$ \\
\hline
\end{tabular}




\begin{tabular}{|c|c|c|c|c|}
\hline & & & & $\begin{array}{l}\text { Nevada Historical } \\
\text { Preservation } \\
\text { Office indicates } \\
\text { that information is } \\
\text { available to those } \\
\text { who meet the } \\
\text { Secretary of the } \\
\text { Interior's standards } \\
\text { for access } \\
\text { (http://shpo.nv.gov } \\
\text { /home/nvcris) }\end{array}$ \\
\hline $\begin{array}{l}\text { New } \\
\text { Hampshire }\end{array}$ & Yes & $\begin{array}{l}\text { New Hampshire } \\
\text { Statutes Title } \\
\text { XIX, Chapter } \\
\text { 227-C }\end{array}$ & Yes & $\begin{array}{l}\text { New Hampshire } \\
\text { Statutes Title XIX, } \\
\text { Chapter 227-C, } \\
\text { Section 227-C:11 } \\
\text { deals with } \\
\text { Confidentiality of } \\
\text { archeological site } \\
\text { locations }\end{array}$ \\
\hline New Jersey & Yes & $\begin{array}{l}\text { New Jersey } \\
\text { Permanent } \\
\text { Statutes Title 13, } \\
\text { 13:1L-10 and } \\
\text { 13:1L-23; 40:10D }\end{array}$ & Yes & $\begin{array}{l}\text { New Jersey } \\
\text { Statutes } 47: 1 \mathrm{~A}-9 \\
\text { exceptions to open } \\
\text { records law if } \\
\text { provided by statute }\end{array}$ \\
\hline New Mexico & Yes & $\begin{array}{l}\text { New Mexico } \\
\text { Statutes } \\
\text { Annotated, } \\
\text { Chapter 18, } \\
\text { Articles 6-1 - 6-17 }\end{array}$ & Yes & $\begin{array}{l}\text { New Mexico } \\
\text { Statutes } \\
\text { Annotated, Section } \\
\text { 18-6-11.1 } \\
\text { information } \\
\text { concerning } \\
\text { archaeological } \\
\text { sites is confidential }\end{array}$ \\
\hline New York & Yes & $\begin{array}{l}\text { New York Parks, } \\
\text { Recreation \& } \\
\text { Historic } \\
\text { Preservation Law } \\
\text { PAR Title C, } \\
\S 14.01-14.09\end{array}$ & Yes & $\begin{array}{l}\text { New York Parks, } \\
\text { Recreation \& } \\
\text { Historic } \\
\text { Preservation Law } \\
\text { PAR Title C, } \\
\text { Article } 14.07 \text { (f) } \\
\text { restricts access to } \\
\text { archaeological } \\
\text { information in } \\
\text { state register }\end{array}$ \\
\hline $\begin{array}{l}\text { North } \\
\text { Carolina }\end{array}$ & Yes & $\begin{array}{l}\text { North Carolina } \\
\text { General Statutes, } \\
\text { Chapter } 70\end{array}$ & Yes & $\begin{array}{l}\text { North Carolina } \\
\text { General Statutes } \\
70-18 ; \text { information } \\
\text { can be made } \\
\text { available unless } \\
\text { the Department of } \\
\text { Cultural Resources } \\
\text { decides that }\end{array}$ \\
\hline
\end{tabular}




\begin{tabular}{|c|c|c|c|c|}
\hline & & & & $\begin{array}{l}\text { disclosure could } \\
\text { harm the resource; } \\
\text { North Carolina } \\
\text { Administrative } \\
\text { Code 04R.806 } \\
\text { information is } \\
\text { confidential }\end{array}$ \\
\hline North Dakota & Yes & $\begin{array}{l}\text { North Dakota } \\
\text { Century Code } \\
\text { Chapter 55-03; } \\
55-10\end{array}$ & Yes & $\begin{array}{l}\text { North Dakota } \\
\text { Century Code 55- } \\
02-07.1 \text {. protects } \\
\text { information on } \\
\text { prehistoric or } \\
\text { historic site } \\
\text { location }\end{array}$ \\
\hline Ohio & Yes & $\begin{array}{l}\text { Ohio Revised } \\
\text { Code Title } 15, \\
\text { Chapter } 1517.24\end{array}$ & Yes & $\begin{array}{l}\text { "access to SHPO } \\
\text { inventory data, } \\
\text { such as the } \\
\text { National Register } \\
\text { of Historic Places, } \\
\text { Ohio Historic } \\
\text { Inventory and the } \\
\text { Ohio } \\
\text { Archaeological } \\
\text { Inventory, is } \\
\text { limited to paid } \\
\text { subscribers. Paid } \\
\text { subscriptions are } \\
\text { strictly limited to } \\
\text { qualified } \\
\text { professionals." } \\
\text { https://www.ohioh } \\
\text { istory.org/preserve } \\
\text { /state-historic- } \\
\text { preservation- } \\
\text { office/mapping; } \\
\text { Ohio Open } \\
\text { Records Law } \\
\text { (Ohio Revised } \\
\text { Code Title I, } \\
\text { Chapter 149, } \\
\text { section A.1 (v)) } \\
\text { exempts records } \\
\text { protected by state } \\
\text { or Federal law }\end{array}$ \\
\hline Oklahoma & Yes & $\begin{array}{l}\text { Oklahoma } \\
\text { Historical } \\
\text { Preservation Act } \\
\text { §53-361 I-K } \\
\text { protects }\end{array}$ & Yes & $\begin{array}{l}\text { Oklahoma } \\
\text { Historical } \\
\text { Preservation Act } \\
\text { \$1- } \\
\text { 24A.13rRecords } \\
\text { generated in }\end{array}$ \\
\hline
\end{tabular}




\begin{tabular}{|c|c|c|c|c|}
\hline & & $\begin{array}{l}\text { archaeological } \\
\text { sites and artifacts }\end{array}$ & & $\begin{array}{l}\text { response to } \\
\text { Federal law can be } \\
\text { kept confidential }\end{array}$ \\
\hline Oregon & Yes & $\begin{array}{l}\text { Oregon Revised } \\
\text { Statutes Chapters } \\
358.905 \text { to } \\
358.961\end{array}$ & Yes & $\begin{array}{l}\text { Oregon Revised } \\
\text { Statutes Chapters } \\
192.501(11) \\
\text { exempts location } \\
\text { of archaeological } \\
\text { sites from } \\
\text { disclosure }\end{array}$ \\
\hline Pennsylvania & Yes & $\begin{array}{l}\text { Statutes of } \\
\text { Pennsylvania } \\
\text { Title } 17 \text { Chapter } \\
\$ 11.209, \S 21.122 \\
\text { and Title } 58 \\
\S 135.2\end{array}$ & Yes & $\begin{array}{l}\text { "Access to } \\
\text { archaeological site } \\
\text { locations and } \\
\text { detailed site } \\
\text { information is } \\
\text { restricted and } \\
\text { password } \\
\text { protected and will } \\
\text { be granted to } \\
\text { qualified } \\
\text { individuals on a } \\
\text { need to know } \\
\text { basis." } \\
\text { https://www.dot7.s } \\
\text { tate.pa.us/CRGIS; } \\
\text { Statutes of } \\
\text { Pennsylvania Title } \\
\text { 101, Part I, } \\
\text { Subpart E, Chapter } \\
\text { 31; Pennsylvania } \\
\text { Right to Know } \\
\text { Law, 2008, P.L. 6, } \\
\text { No. 3, Section 708 } \\
\text { (b) (25) exempts } \\
\text { locations of } \\
\text { archaeological } \\
\text { sites }\end{array}$ \\
\hline Rhode Island & Yes & $\begin{array}{l}\text { Rhode Island } \\
\text { General Laws, } \\
\text { Title 42, Chapter } \\
\text { 42-45.1 }\end{array}$ & Yes & $\begin{array}{l}\text { Rhode Island } \\
\text { General Laws, } \\
\text { Title Title 38, } \\
\text { Chapter 2, Section } \\
\text { 38-2-2 (S) records, } \\
\text { reports, opinions, } \\
\text { information, and } \\
\text { statements } \\
\text { required to be kept } \\
\text { confidential by } \\
\text { Federal law or } \\
\text { regulation or state }\end{array}$ \\
\hline
\end{tabular}




\begin{tabular}{|c|c|c|c|c|}
\hline & & & & $\begin{array}{l}\text { law, or rule of } \\
\text { court. }\end{array}$ \\
\hline $\begin{array}{l}\text { South } \\
\text { Carolina }\end{array}$ & Yes & $\begin{array}{l}\text { South Carolina } \\
\text { Code of Laws } \\
\text { Title 16, Chapter } \\
11, \S 780\end{array}$ & Yes & $\begin{array}{l}\text { Access to location } \\
\text { data restricted to } \\
\text { people who have } \\
\text { been approved for } \\
\text { access: } \\
\text { http://shpo.sc.gov/r } \\
\text { esearch/Pages/Arc } \\
\text { hSite.aspx; South } \\
\text { Carolina Code of } \\
\text { Laws Title } 30, \\
\text { \$30-4-40. exempts } \\
\text { disclosure of } \\
\text { information that is } \\
\text { "specifically } \\
\text { exempted from } \\
\text { disclosure by } \\
\text { statute or law" }\end{array}$ \\
\hline South Dakota & Yes & $\begin{array}{l}\text { South Dakota } \\
\text { Codified Laws } \\
\text { Title 1, Chapter } \\
20\end{array}$ & Yes & $\begin{array}{l}\text { South Dakota } \\
\text { Codified Laws } \\
\text { Title 1, Chapter } \\
\text { 20, 1-20-21.2 } \\
\text { archaeological } \\
\text { records are } \\
\text { confidential }\end{array}$ \\
\hline Tennessee & Yes & $\begin{array}{l}\text { Tennessee Code } \\
\text { Annotated Title } \\
\text { 11, Chapter } 6\end{array}$ & Yes & $\begin{array}{l}\text { Tennessee Code } \\
\text { Annotated Title } \\
\text { 10, Chapter 7, Part } \\
5,10-7-503(7)(\mathrm{C}) \\
\text { (b) government } \\
\text { agencies can set up } \\
\text { rules for access if } \\
\text { Federal law } \\
\text { requires } \\
\text { confidentiality }\end{array}$ \\
\hline Texas & Yes & $\begin{array}{l}\text { Texas Natural } \\
\text { Resources Code, } \\
\text { Title 9, Chapter } \\
191\end{array}$ & Yes & $\begin{array}{l}\text { Texas Natural } \\
\text { Resources Code } \\
\text { Title 9, Sec. 191, } \\
\text { subsection } 004 \\
\text { requires } \\
\text { information about } \\
\text { archaeological } \\
\text { sites to be } \\
\text { confidential }\end{array}$ \\
\hline
\end{tabular}




\begin{tabular}{|c|c|c|c|c|}
\hline Utah & Yes & $\begin{array}{l}\text { Utah Code Title } \\
9 \text {, Chapter } 8 \text {, Part } \\
3, \S 301-309\end{array}$ & Yes & $\begin{array}{l}\text { Utah Code Title } \\
63 \mathrm{G} \text {, Chapter 2, } \\
\$ 305 \text {, Subsection } \\
26 \text { protects the } \\
\text { location of historic } \\
\text { and prehistoric } \\
\text { sites }\end{array}$ \\
\hline Vermont & Yes & $\begin{array}{l}\text { Vermont Statutes } \\
\text { Online Title } 22 \text {, } \\
\text { Chapter } 14, \\
\text { Subchapter } 11\end{array}$ & Yes & $\begin{array}{l}\text { Vermont Statutes } \\
\text { Online Title } 22, \\
\text { Chapter } 14, \\
\text { Subchapter } 7, \S \\
761,(b) \\
\text { information on } \\
\text { archaeological } \\
\text { sites is confidential }\end{array}$ \\
\hline Virginia & Yes & $\begin{array}{l}\text { Code of Virginia } \\
\text { Title 10.1, } \\
\text { Subtitle III, } \\
\text { Chapter } 23\end{array}$ & Yes & $\begin{array}{l}\text { Data cannot be } \\
\text { released to the } \\
\text { public: } \\
\text { http://www.dhr.vir } \\
\text { ginia.gov/archives/ } \\
\text { TermsAndConditi } \\
\text { ons.pdf; sites } \\
\text { exempted from } \\
\text { release in Freedom } \\
\text { of Information } \\
\text { Act: Code of } \\
\text { Virginia } \$ 2.2- \\
3705.7(10),\end{array}$ \\
\hline Washington & Yes & $\begin{array}{l}\text { Revised Code of } \\
\text { Washington Title } \\
27 \text {, Chapter } 27.53\end{array}$ & Yes & $\begin{array}{l}\text { Revised Code of } \\
\text { Washington Title } \\
42, \text { Chapter 56, } \\
\text { Section } 300 \\
\text { archaeological } \\
\text { sites exempt from } \\
\text { disclosure }\end{array}$ \\
\hline West Virginia & Yes & $\begin{array}{l}\text { West Virginia } \\
\text { Code } \$ 29-1-8 \mathrm{a}\end{array}$ & Yes & $\begin{array}{l}\text { West Virginia } \\
\text { Code } \$ 29 B-1-4 \text { (6) } \\
\text { exempts } \\
\text { archaeological } \\
\text { sites }\end{array}$ \\
\hline Wisconsin & Yes & $\begin{array}{l}\text { Wisconsin } \\
\text { Statutes } 44.47\end{array}$ & Yes & $\begin{array}{l}\text { Wisconsin Statutes } \\
44.48 \text { (c) exempts } \\
\text { archaeological } \\
\text { sites }\end{array}$ \\
\hline Wyoming & Yes & $\begin{array}{l}\text { Wyoming Statutes } \\
\text { Title } 36 \text {, Article } \\
1-114 \text { to } 1-116\end{array}$ & Yes & $\begin{array}{l}\text { Wyoming Statutes } \\
\text { Title 16, Article 4- } \\
203 \text { exempts } \\
\text { information that is } \\
\text { protected by state } \\
\text { or Federal statutes; }\end{array}$ \\
\hline
\end{tabular}




\begin{tabular}{|l|l|l|l|}
\hline & & & $\begin{array}{l}\text { Cultural resource } \\
\text { Database access } \\
\text { cites NHPA }\end{array}$ \\
\hline
\end{tabular}


Table 2. State cave protection laws in the United States showing laws protecting caves and whether cave locations are confidential.

\begin{tabular}{|c|c|c|c|}
\hline State & $\begin{array}{l}\text { Cave } \\
\text { Law? }\end{array}$ & Code Citation & $\begin{array}{l}\text { Location } \\
\text { Confidential? }\end{array}$ \\
\hline Alabama & Yes & Alabama Code, Title 9, Chapter 19 & No \\
\hline Arizona & Yes & $\begin{array}{l}\text { Arizona Revised Statutes, Title 13, Chapter } \\
3702\end{array}$ & No \\
\hline Arkansas & Yes & $\begin{array}{l}\text { Arkansas Code, } \$ 15-20-605 \text { (Title 15, } \\
\text { Subtitle 2. Chapter 20, Subchapter 6) }\end{array}$ & No \\
\hline California & Yes & $\begin{array}{l}\text { California Penal Code, Part 1, Title 14, } \\
\text { section } 623\end{array}$ & No \\
\hline Colorado & Yes & Colorado Revised Statutes §18-4-509 & No \\
\hline Florida & Yes & Florida Statutes, Title XLVI, Chapter 810 & No \\
\hline Georgia & Yes & $\begin{array}{l}\text { Code of Georgia, Title 12, Chapter } 4, \\
\text { Article } 4\end{array}$ & No \\
\hline Hawaii & Yes & $\begin{array}{l}\text { Hawaii Revised Statutes, Title 1, Chapter } \\
6 \mathrm{D} \text { (Title 1, Chapter 6D, section } 10 \text { allows } \\
\text { confidentiality) }\end{array}$ & Yes \\
\hline Idaho & Yes & $\begin{array}{l}\text { Idaho Statutes Title 18, Chapter 70, } \\
\text { Section } 7035\end{array}$ & No \\
\hline Illinois & Yes & $\begin{array}{l}525 \text { Illinois Compiled Statutes, Cave } \\
\text { Protection Act } \S 5\end{array}$ & No \\
\hline Indiana & Yes & $\begin{array}{l}\text { Indiana Code, Title 35, Article 43, Chapter } \\
1\end{array}$ & No \\
\hline Kentucky & Yes & $\begin{array}{l}\text { Kentucky Revised Statutes Title XL, } \\
\text { Chapter 433.871-885 }\end{array}$ & No \\
\hline Maine & Yes & $\begin{array}{l}\text { Maine Revised Statutes, Title 12, Chapter } \\
\text { 201-A, Subchapter 1-A }\end{array}$ & No \\
\hline Maryland & Yes & $\begin{array}{l}\text { Maryland Statutes, Natural Resources Title } \\
\text { 5, Subtitle 14; Disclosure of sites exempt } \\
\text { Maryland Annotated Code article GGP, } \S \\
\text { 4-350 }\end{array}$ & Yes \\
\hline Missouri & Yes & $\begin{array}{l}\text { Missouri Revised Statutes } \$ 578.0200 .2- \\
578.0215 .1 \text { (Until December 31, 2016); } \\
\text { Missouri Revised Statutes } \$ 569.0135 .1- \\
\text { 569.0137.1 (Beginning January 1, 2017) }\end{array}$ & No \\
\hline Montana & Yes & $\begin{array}{l}\text { Montana Code Annotated, Title 23, } \\
\text { Chapter 2, Part } 9\end{array}$ & No \\
\hline Nevada & Yes & $\begin{array}{l}\text { Nevada Revised Statutes: NRS } \S 206.330 \\
\text { Protects caves from malicious mischief; } \\
\text { NRS } \S 381.195-381.227 \text { Protects them as } \\
\text { sites }\end{array}$ & No \\
\hline New Mexico & Yes & $\begin{array}{l}\text { New Mexico Statutes, Chapter 30, Article } \\
15-5\end{array}$ & No \\
\hline North Carolina & Yes & $\begin{array}{l}\text { North Carolina General Statutes, Chapter } \\
\text { 14, Article 22C, } 159.20-159.23\end{array}$ & No \\
\hline Ohio & Yes & Ohio Revised Code $\S 1517.21-1517.22$ & No \\
\hline
\end{tabular}




\begin{tabular}{|l|l|l|l|}
\hline Oklahoma & Yes & Oklahoma Statutes, Title 21, Section 1789 & No \\
\hline Pennsylvania & Yes & $\begin{array}{l}\text { Statutes of Pennsylvania, Unconsolidated } \\
\text { Statutes, 1990 Act 133 }\end{array}$ & No \\
\hline Tennessee & Yes & Tennessee Code Annotated § 11-5-108 & No \\
\hline Texas & Yes & $\begin{array}{l}\text { Texas Natural Resources Code, Title 10, } \\
\text { Chapter 201 }\end{array}$ & No \\
\hline Vermont & Yes & $\begin{array}{l}\text { Vermont Statutes Online, Title 22, Chapter } \\
14\end{array}$ & No \\
\hline Virginia & Yes & $\begin{array}{l}\text { Code of Virginia, Title 10, Chapter 10; } \\
\text { Title 2.2 Chapter 37, § 3705.7.10 exempts } \\
\text { caves }\end{array}$ & Yes \\
\hline West Virginia & Yes & $\begin{array}{l}\text { West Virginia Code, Chapter 20. Article } \\
7 A\end{array}$ & No \\
\hline Wisconsin & Yes & Wisconsin Statutes § 943.01 & No \\
\hline
\end{tabular}

